\title{
The Need to Return to a Monetary Framework
}

\author{
John B. Taylor ${ }^{1}$
}

January 2009

Sometime in mid September 2008, the Federal Reserve began creating money at an amazingly rapid pace. For the week ending September 10, banks and other depository institutions held $\$ 8$ billion in deposits at the Fed. By the week ending December 31, 2008, they held \$848 billion. Such deposits are commonly called “reserve balances.” They are the key component—along with currency_of base money or central bank money which the Federal Reserve is responsible for controlling. Hence, the Fed had increased the supply of reserve balances by 100 -fold in a very short period of time.

Although the reasons for the unprecedented increase are complex, it is important to try to understand them and explain them as simply as possible. To do so one must delve into the details of the Federal Reserve's balance sheet and sort out the forces likely to shift the supply and demand for reserve balances in a financial crisis. In this paper I use a series of graphs to show what happened to the major items on the balance sheet during this period and then identify the key factors underlying the increase in reserve balances. I show that the increase came about as a direct result of the Fed's decision to purchase securities and make loans to certain sectors and institutions. In other words the Fed financed these securities purchases and loans by creating

${ }^{1}$ Professor of Economics, Stanford University and Senior Fellow, Hoover Institution. Prepared for the National Association of Business Economics Panel, "Long-Run Economic Challenges: A Federal Reserve Perspective," San Francisco, January 3, 2009 and forthcoming in Business Economics, Vol. 43, No 2, April 2009. I wish to thank Josie Smith and Johannes Stroebel for helpful research assistance. 
reserve balances — creating money. The increase in the supply of reserve balances was not, for the most part, a result of the Fed accommodating an increase in the demand for money (or a reduction in desired velocity), as had occurred in earlier episodes of sharp increases in reserve balances such as around September 11, 2001. Nor was it the result of the New York Fed’s trading desk adjusting reserve balances to implement the interest rate directive of the Federal Open Market Committee (FOMC); in fact the increase in reserve balances drove the federal funds rate way below the FOMC's directives at the time. And it was certainly not the result of decisions to increase the growth rate of the money supply by a certain calibrated amount in order to affect the real economy or inflation. I think it is best understood as a type of industrial policy_assisting certain sectors and firms — financed by monetary policy. The combination might be called mondustrial policy.

This characterization of the reasons for the large increase in reserve balances raises a number of important public policy questions and governance issues which deserve a wide and thorough discussion. In my view, it is important to return as quickly as possible to a clear monetary policy framework. The federal funds rate is now effectively zero and cannot go lower. The reduction in the effective federal funds rate from 2 percent, where it was when the large expansion of money began, to 0 percent was a direct result of the massive increase in central bank money. The FOMC decisions to lower the target for the federal funds rate apparently followed the declines in the federal funds rate, effectively ratifying them. But whatever the reason, as long as the overnight interest rate is at zero, the monetary policy framework needs to focus on the level or the growth rate of the quantity of money. As soon as conditions warrant, the policy framework should again focus on systematic procedures for setting the overnight interest rate-a policy which works well, as has been demonstrated during the great moderation period 
of the past quarter century. If policy does not go back to a monetary policy framework, then questions must be raised about the fundamental role, independence, and governance structure of the Federal Reserve.

I begin by laying out a conceptual way to think about such a framework and then examine actual policy. My empirical analysis covers the period through December 31, 2008, the latest day data were available when this paper was presented (on January 3). Updates of the charts will be made available over time.

\section{A Conceptual Framework}

A wide variety of monetary policy frameworks have been discussed and debated over the years. Among frameworks which focus on the instruments of monetary policy there are two broad types: those that focus on the interest rate and those that focus on quantity of money. Among the latter we have seen various quantity measures proposed, including the monetary base, several of the monetary aggregates, reserves, free reserves, and borrowed reserves. Because the overnight federal funds rate has a lower bound of zero, even a monetary policy framework that usually focuses on the interest rate needs to make use of a quantity measure when the interest rate hits zero.

Figure 1 summarizes a conceptual way to think about such a framework. I originally designed this diagram for the Bank of Japan while an adviser in the 1990s. (See Taylor (2001)). 


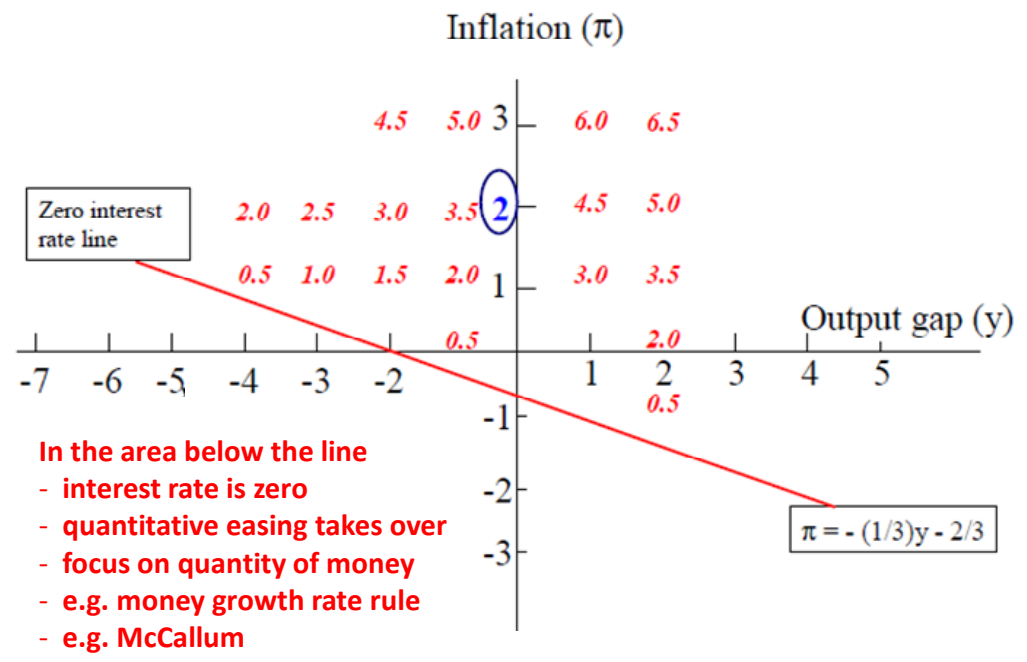

Figure 1. A Monetary Framework That Incorporates Quantitative Easing

The inflation rate is on the vertical axis and the output gap is on the horizontal axis. The numbers in italics are the interest rate settings according to the Taylor rule. The downward sloping line shows when the lower bound on the interest rate is hit according to such a rule. It is obtained by substituting a zero interest rate into a Taylor rule. For the area below the line, the interest rate is zero and policy makers must look at some quantity such as the money supply or the monetary base; this is the region of quantitative easing. In this lower region, policy makers could use Milton Friedman's famous constant growth rate rule, or the money base rule proposed by McCallum (1988). Or policy makers could design another procedure for determining the quantity based on economic principles. For the Friedman rule a monetary aggregate would grow at a constant rate, say 4 percent. For the McCallum rule the growth of the monetary base is flexible, but would be around 4 percent according to conditions near the end of 2008 . 
Figure 1 illustrates that one should not think of quantitative easing as a separate or different framework for monetary policy, but rather as part of a broader framework. Any point in the region below the line is clearly undesirable, and the hope is that policy will help take the economy back above the line as soon as possible. Christiano and Rostagno (2001) have shown how such a broader framework could work technically, incorporating it into a macroeconomic model, although they assume that policy makers start targeting money growth when actual money growth falls below a certain level rather than when a combination of inflation and the output gap falls below zero.

The federal funds rate went to zero in the last quarter of 2008 so the Fed has gone into the quantitative easing region. In the next section I examine the Fed's balance sheet and try to characterize the type of quantitative easing that has been followed. I start by showing that the increases in reserve balances are orders of magnitude greater than the money growth rates proposed by McCallum or Friedman.

\section{The Explosion of Reserve Balances}

Figure 2 illustrates the unprecedented nature of the increase in reserve balances. For years reserve balances had usually fluctuated around the 7 to 12 billion dollar range; by adjusting the amount of reserve balances-largely through open market operations-the trading desk of the New York Fed carried out the directives of the Federal Open Market Committee in maintaining its overnight federal funds target. 


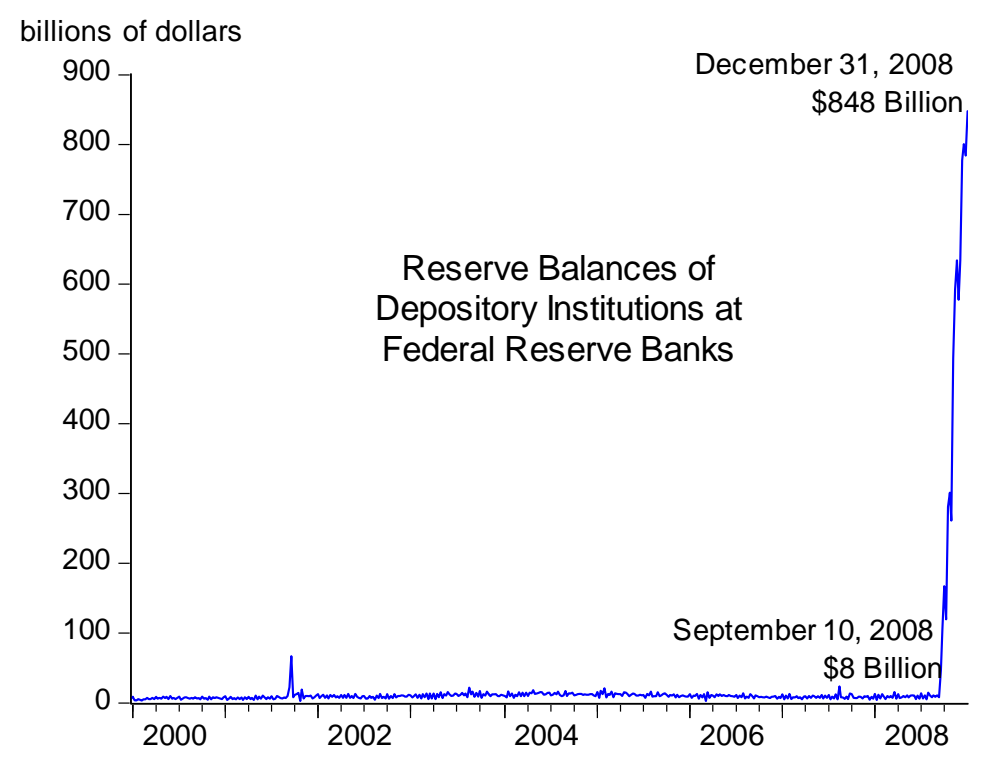

Figure 2. Reserve Balances 2000-2008

The only exception before 2008 was the relatively small blip around September 11, 2001when physical damage and delays in the payments system increased the demand for reserve balances by banks, and the Fed masterfully supplied them to keep the payments system running smoothly.

Figure 3 shows in more detail what happened during that 9/11 period. Observe how the supply of reserves were first increased and then were drawn down equally rapidly. While this looks like a small blip in Figure 2, it was viewed as very large and unusual at the time. I can attest to this because I had just completed a research project (Taylor (2000)) on the New York Fed's trading desk operations in the late 1990s; around the time of 9/11 Donald Kohn, then on the staff of the Federal Reserve Board, kindly shared the daily numbers with me while I was at the U.S. Treasury and we marveled together at their size and at the rapidity at which they came and went. 


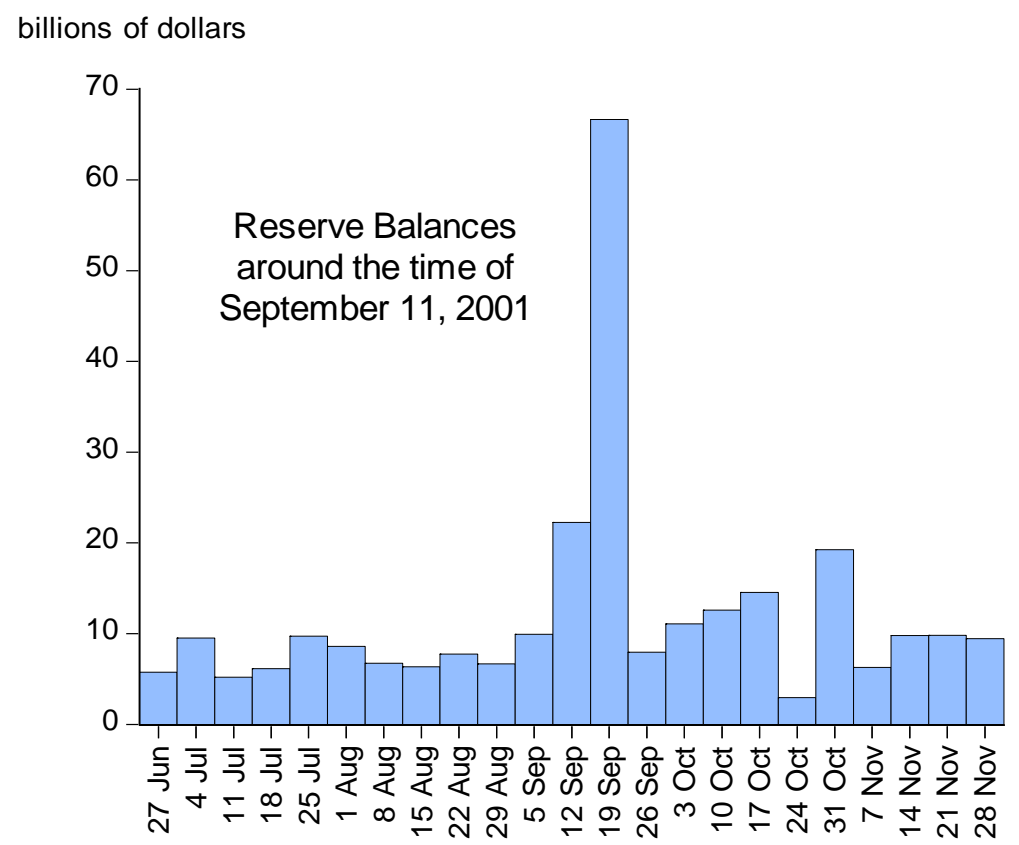

Figure 3. Reserve Balances, Weekly Averages, 27 June to 28 November 2001

The increase in reserve balances in 2008 differed in both magnitude and timing from that in 2001. To see this, compare Figure 3 with Figure 4, which gives the weekly details for 2008. Observe that the increase in reserve balances was much larger and was not quickly withdrawn in the later period. I show both weekly averages and Wednesday levels in Figure 4. Daily data on the Fed's balance sheet is not released to the public, but by comparing Wednesday levels one can infer a little about daily developments during the week. For example the Wednesday numbers show that the first large increase in reserve balances occurred sometime between September 10 and September 17. This will help us identify the reason for the increase and in particular whether it was due to a shift in demand or supply as I explain below. In the next section, I show 
how the behavior of the supply of reserve balances can be understood by examining the details of Fed's balance sheet. I focus on the period in Figure 4.

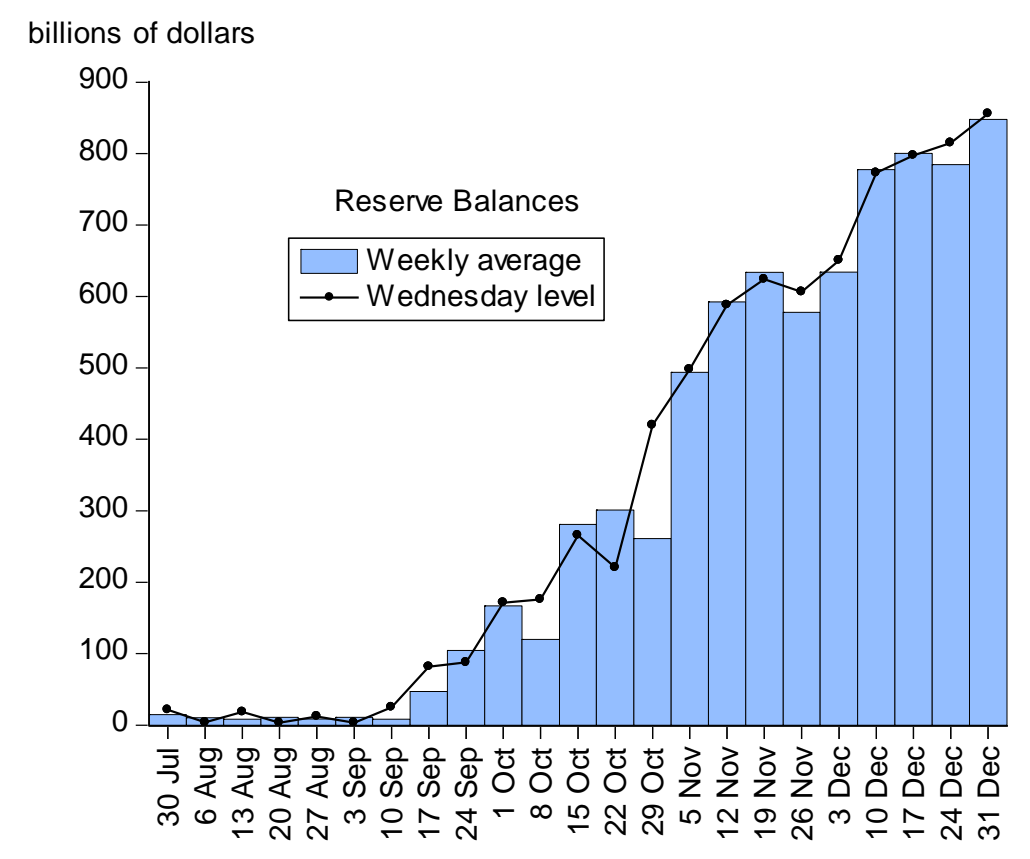

Figure 4. Reserve Balances, Weekly Average, Wednesday Levels, 30 July to 31 Dec 2008

\section{Looking Through the Balance Sheet for Reasons Why Reserve Balances Exploded}

The Fed's balance sheet data are published each week in the Federal Reserve Board H.4.1 release, which is the source of the data used in this paper. Reserve balances are shown as one line in the balance sheet and are best viewed as a residual determined by all the other items on the balance sheet. At the most general level, reserve balances are equal to all factors "supplying reserves” less the all factors (other than reserve balances) "absorbing reserves.” In less technical terms, the factors supplying reserves are essentially all the assets on the Fed's balance sheet. The 
factors absorbing reserves are essentially all the items on the liability side of the Fed's balance sheet, except of course for reserve balances.

I illustrate this in Figure 5. The total height of the bars in Figure 5 represents the amount in billions of dollars of total factors supplying reserves. (Note that the vertical scale of Figure 5 starts at $\$ 800$ billion so that the absorbing factors are quite a bit larger than a first glance at the graph would suggest). The bottom part of each bar is the amount of factors absorbing these reserves (other than reserve balances). The difference between the two-shown by the upper part of the bars-represents reserve balances; this is the same number found in Figure 4. To determine reserve balances we first examine total factors supplying reserves and then consider the absorbing factors. Observe that neither the supplying factors nor absorbing factors changed much until September 17. Then both started to increase, but because total supplying factors increased faster, a large gap was created, which accounts for the increase in reserve balances.

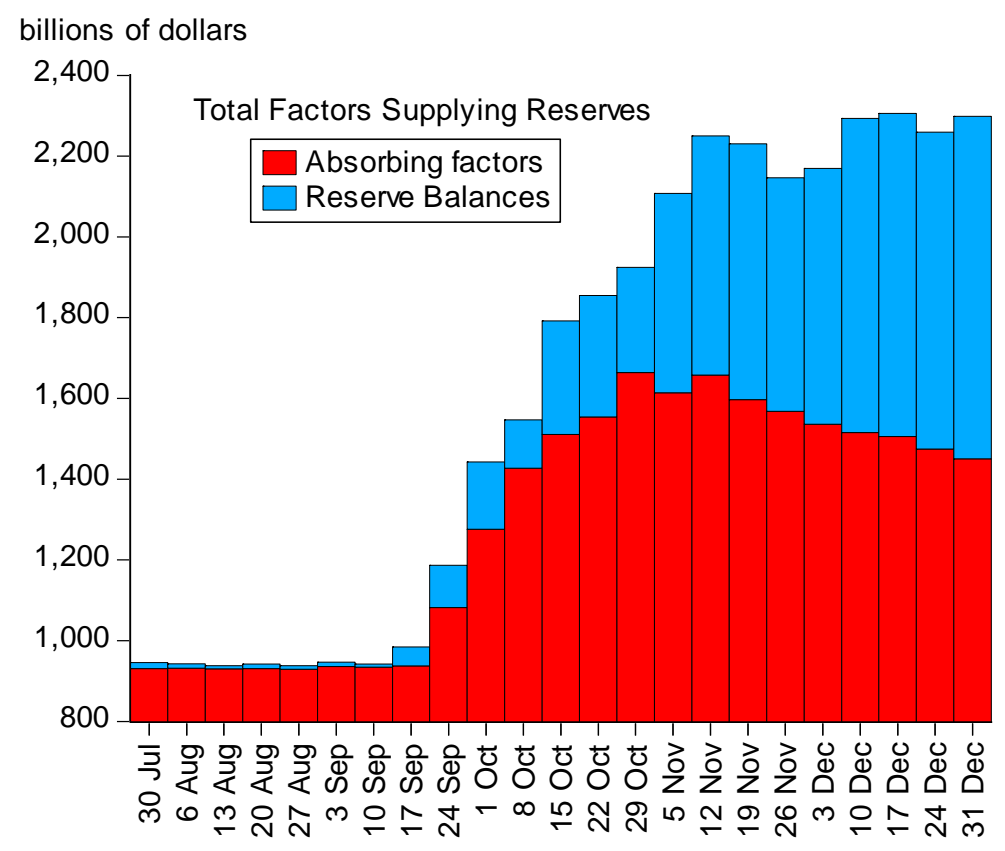

Figure 5. Reserve Balances: Equal to Supplying Factors less Absorbing Factors 
A list of the major factors supplying reserves is shown in Table 1. There are other factors including the gold stock, special drawing rights (SDR) of the IMF, Treasury currency outstanding, seasonal and secondary discount loans, and float, but these either did not change during the period in question or changed by a minimal amount. A few of the items in Table 1 are familiar to students of economics as the classic ways that the Fed controls reserve balances and the money supply. These are the items with the regular font. In classic open market operations, the Fed buys and sells securities (the first line) and thereby increases or decreases the supply of reserves. When it engages in repurchase agreements (repos in the second line) it supplies reserves; repos have traditionally been reserved for relatively temporary injections of reserve balances. The primary credit facility is the classic discount window; when banks borrow from the Fed, their reserve balances increase. The last line in the Table 1, “Other Federal Reserve Assets,” is largely loans to foreign central banks which also increase reserve balances.

Most of the items in Table 1, however, did not exist before the financial crisis and have been created as a result of the financial crisis. I have marked these new items in the italic font. The first new facility was the Term Auction Facility (TAF), created in December 2007. The Primary Dealer Credit Facility (PDCF) was created in March 2008 around the time of the Bear Stearns intervention. The rest of the new loan items were created in the last few months of 2008 and are discussed below. In addition the Fed now has a portfolio of private assets on its books, such as commercial paper and assets from Bear Stearns and AIG. I used italic font for the description in parentheses under “other federal reserve assets” because this has increased by a huge amount since the crisis began and is therefore as unusual as the other italicized items. 
Table 1 The Major Factors Supplying Reserves

Securities (Treasury and Agency) held outright

Repos

Loans from the TAF

Other Loans

o Primary Credit Facility (discount window)

o Primary Dealer Credit Facility

o Asset Back Commercial Paper Money Market Mutual Fund Liquidity Facility

o Loans to AIG

o Term Asset-Backed Securities Loan Facility (credit card, student, auto)*

Private Portfolio holdings

o Commercial Paper Funding Facility

o Maiden Lane I (Bear Stearns)

o Maiden Lane II (AIG)

o Maiden Lane III (AIG)

o Money Market Investor Funding Facility*

o Mortgage Backed Securities Purchase Program*

Other Federal Reserve Assets (very large loans to foreign central banks)

Note: New programs have a red/italic font. An asterisk represents a program that were yet not activated at the time of presenting this paper on January 3, 2008

My objective is now to examine the time series behavior of each of the items during the period that reserve balances increased. Figures 6, 7, and 8 show the time patters for each of the items during the period under study. Figure 6 corresponds to the six main categories in Table 1 including the categories "other loans” and "private portfolio holdings.” Figure 7 then shows the details for other loans and Figure 8 shows the details for private portfolio holdings. By moving back and forth between these three figures you can see where most of the action has been.

Figure 6 makes it clear that almost all of increase in supply was due to purchases of securities and loans from the new Fed facilities. The term auction facility, the private portfolios, and the new loans to foreign central banks show the largest increases by the end of the year. 
Among these three categories, loans to foreign central banks show the largest increase. They jumped by about $\$ 560$ billion from September to November. (Recall that these loans are in the “other Federal Reserve assets” category; the $\$ 560$ billionis an estimate that comes from subtracting $\$ 40$ billion from $\$ 600$ billion the approximate amounts of “other Federal Reserve assets" at the start and finish of this period.) Neither of the two traditional ways to increase reserves—securities and repos—moved much at all.

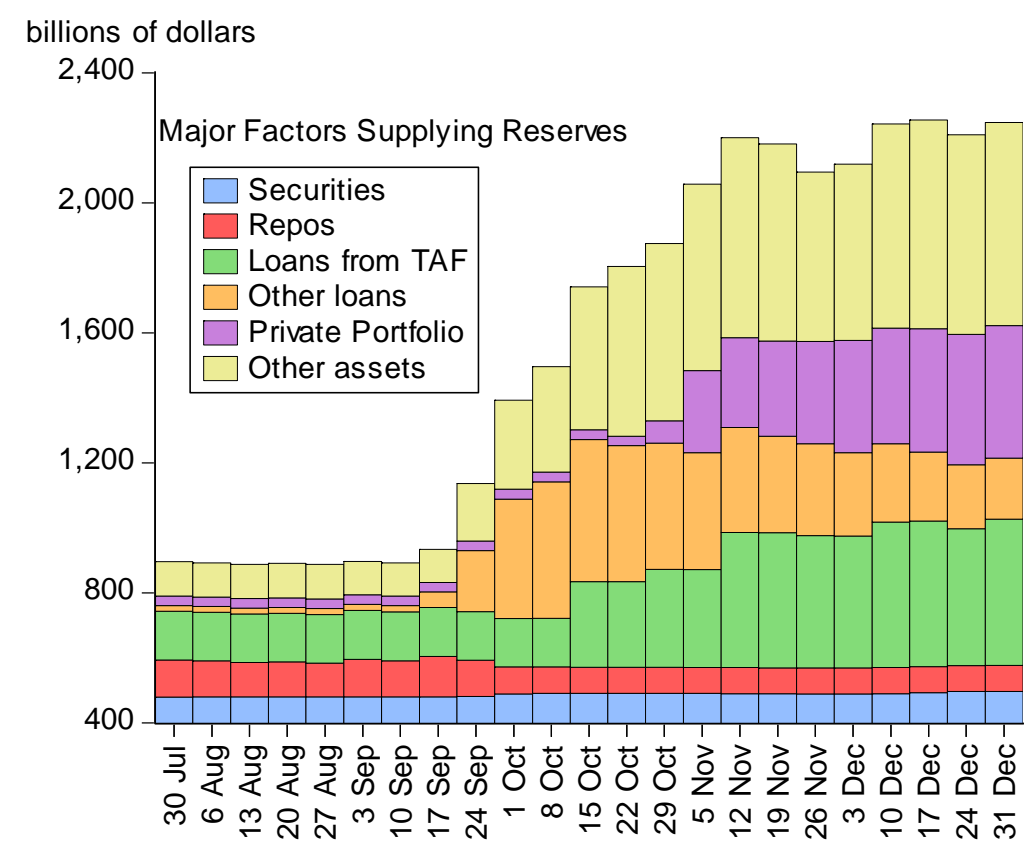

\section{Figure 6. Developments Over Time in Major Factors Supplying Reserves}

Figure 7 shows that early-on the largest increase was the due to the loans from the PDCF, which were in turn due to extensive demand for borrowing after the bankruptcy of Lehman Brothers. Loans to AIG and the new Asset Backed Commercial Paper Money Market Mutual Fund Liquidity Facility were also large. Later in the period depository institutions upped their primary credit borrowing from the discount window. 


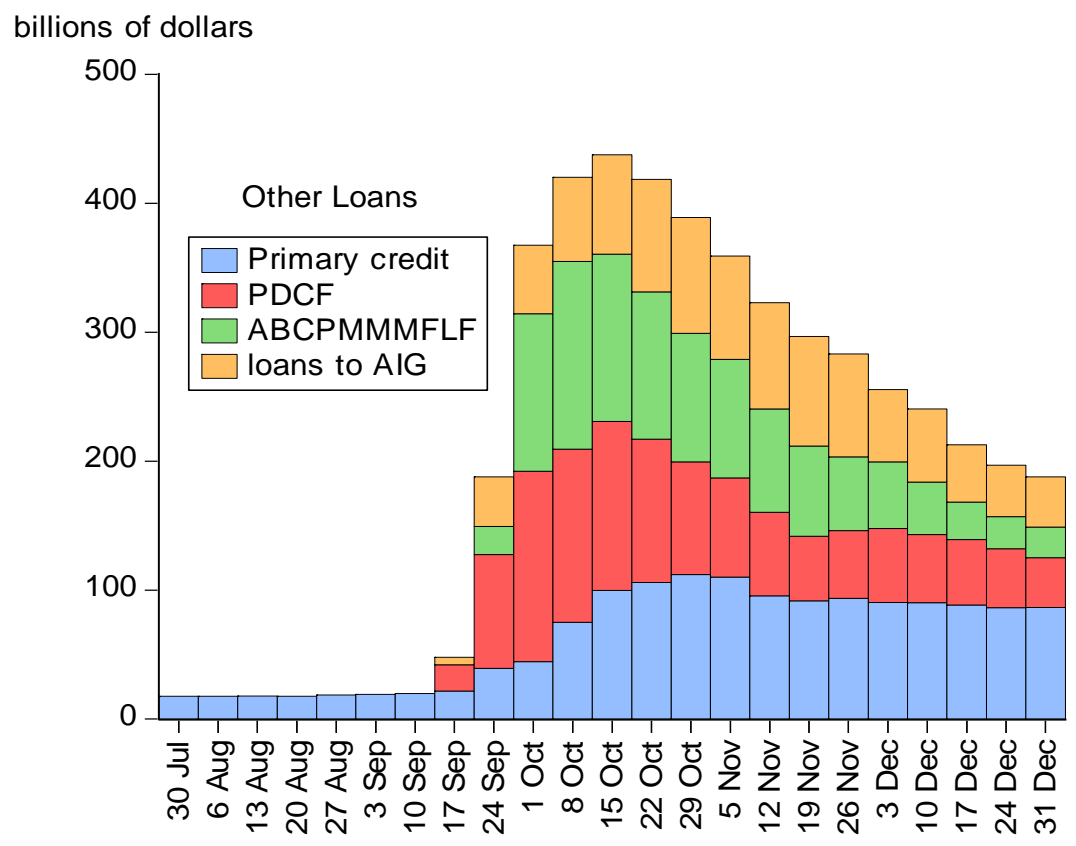

Figure 7. Components of the Other Loan Category on the Fed's Balance Sheet

Figure 8 shows that the biggest part of the private portfolio as of the end of 2008 was for the holdings of commercial paper. The Commercial Paper Funding Facility was created in late October to relieve pressures in the commercial paper market, and shows the biggest increase at that time. The three Maiden Lane portfolios consist of the assets from AIG and Bear Stearns. These are comparatively smaller, though still large in absolute amount. 


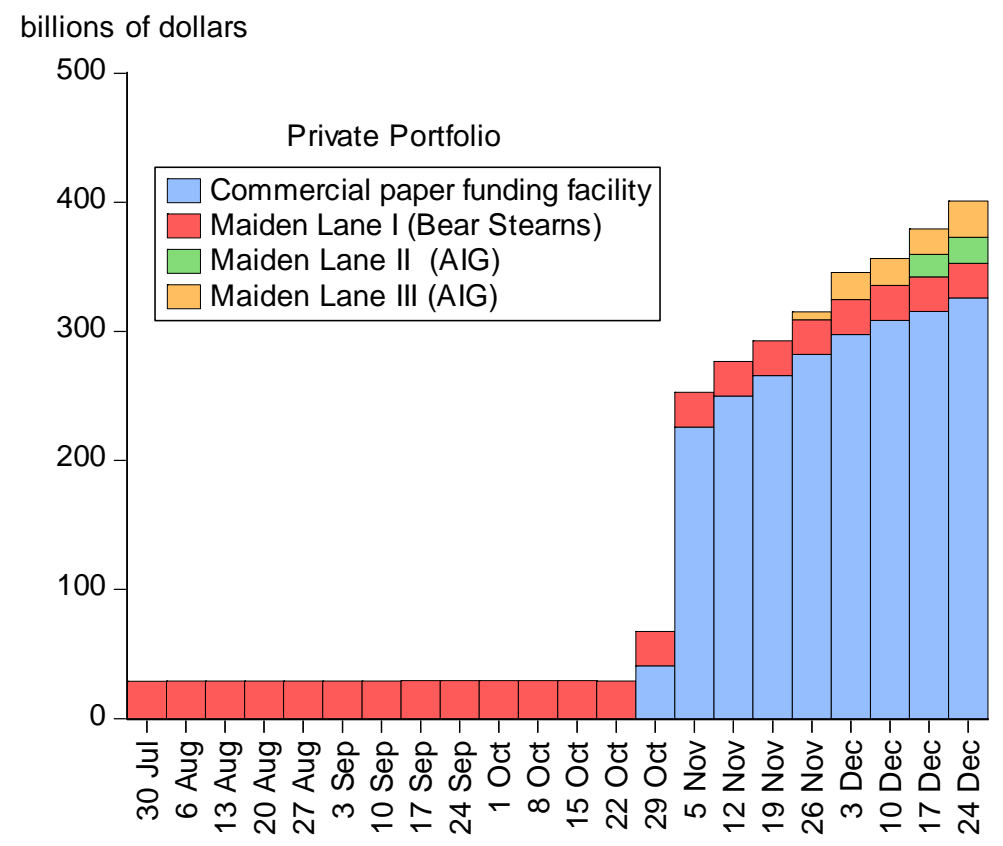

\section{Figure 8. Components of the Private Portfolio on the Fed's Balance Sheet}

Finally we can look at the factors absorbing reserves in Figure 9. By far the largest change in this item was a special supplementary deposits program of the U.S. Treasury. Under this program the Treasury would borrow funds and deposit them at the Fed. Since the Fed serves as the Treasury’s bank, the Treasury always has some deposits at the Fed and these increased somewhat in November and December. But this increase was small compared with the \$500 billion increase in deposits by the end of October through the special supplementary program. However, this special account was being drawn down by the end of the year. This drawdown has led to a decline in the total amount of absorbing factors and a corresponding increase in reserve balances as shown back in Figure 5. 


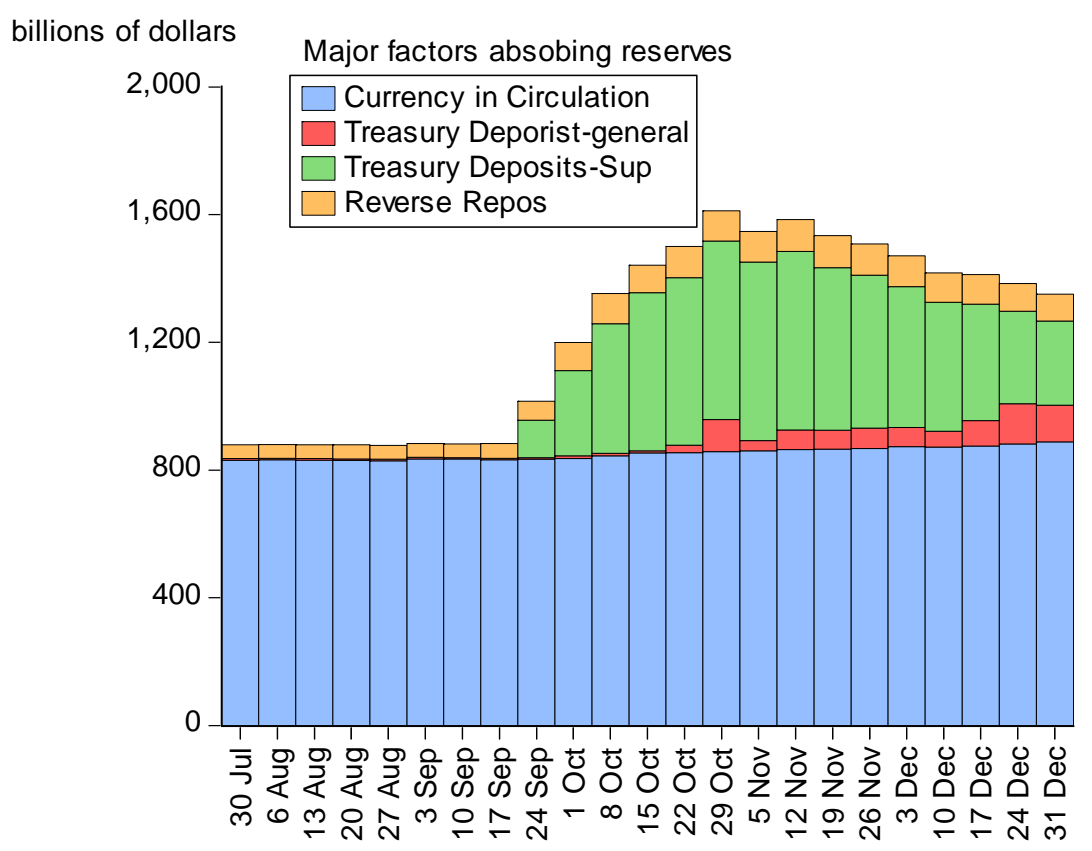

\section{Figure 9. Changes Over Time in the Factors Absorbing Reserves}

Now, what does one learn from wading through all these data besides a greater understanding of the dynamics of the Fed's assets and liabilities? Most important is that the real reason for the large increase in reserve balances was most likely an increase in supply rather than such alternative reasons as accommodation of an increase in the demand for reserves, the payment of interest on reserves, an exogenous decline in the money multiplier, or an increase in the demand for the monetary aggregates, as some have argued or believed. We will want to consider these other possibilities and other evidence, but this look at the Fed's balance sheet suggests that a policy of purchasing private securities and making loans to certain sectors and firms has been financed by increasing reserve balances and that is the reason for the explosion of reserve balances. 


\section{Evidence from Wednesday Levels on September 10 and September 17}

Other considerations bolster this conclusion. Figure 10 focuses on the week ending September 17 when reserve balances first rose by unusual amounts. It looks at Wednesday levels rather than the weekly averages. Observe that the increase in loans to investment banks through the PDCF from 10 September to 17 September (\$60 billion) was very close in size to the increase in reserve balances ( $\$ 58$ billion). This is more evidence that the PDCF increase was being financed by central banks money creation.

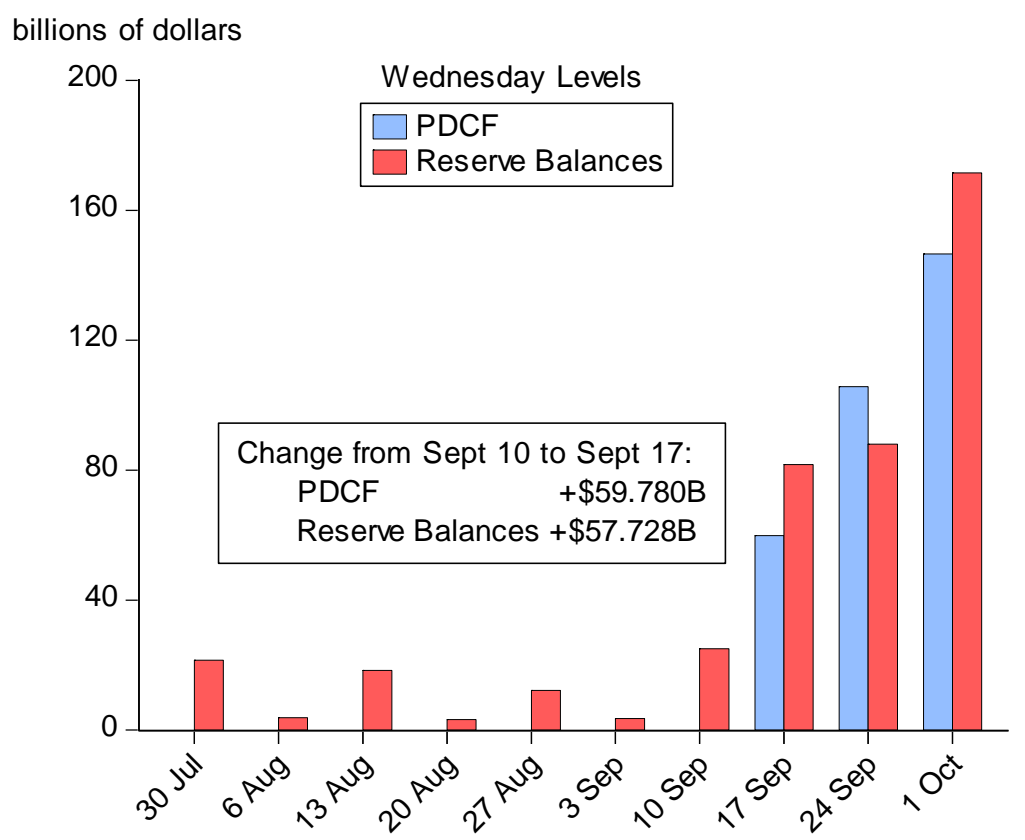

Figure 10. The Close Relation Between Reserve Balances and the PDCF 


\section{On What Day Did the Fed Stop Sterilizing and Why?}

Figure 10 raises an important question. September 17 was the first week since the beginning of the crisis that the Fed did not "sterilize" the increase in loans by selling off some of its government securities. But what day did it stop sterilizing, and who made this important decision to increase reserve balances, and why? Because the Fed does not publish daily data we cannot pinpoint the day of the decision, but we can still guess some reasons for the decision.

Was the Fed concerned that the stock of Treasury securities was already too low? Although the stock had been depleted during the first year of the crisis, it was still over $\$ 400$ billion. Perhaps the Fed wanted to be able to loan these securities as part of its securities lending program.

Another possible answer is that the Fed simply decided that making loans through the PDCF at that time was so essential that it should be done even if it could not be sterilized, even if that created a downward pressure on the funds rate.

A third possibility was that the Fed was planning to pay interest on reserves and thought that doing so would keep the funds rate from declining even with a large increase in reserve balances.

\section{Evidence in an FAQ}

More direct evidence that the increase in reserves was due to a shift in supply is a posting on the New York Fed's web page in December stating that this would be the policy going forward, implying that this was the policy since September. In particular an FAQ posted on December 30, 2008 as part of the new Mortgage Backed Securities (MBS) purchase program was: 
Q: How will purchases under the agency MBS program be financed?

A: Purchases will be financed through the creation of additional bank reserves. Although this question and answer only pertains to the MBS program, one might presume that the intention was to finance others securities purchases and loans by money creation. It is this perspective that leads one to think of the policy as a combination of industrial policy and monetary policy, and to use the term mondustrial policy.

\section{Identifying Shifts in Supply and Demand}

Now let us consider some of the other explanations. One is that the Fed accommodated an increased demand for reserves by banks, as it apparently did around 9/11, due to a flight to safety. If there were such a shift in demand one would expect there to have been upward pressure on the federal funds interest rate; an accommodative supply response would then have alleviated that upward pressure, but would not have created downward pressure.

Figure 11 plots the federal funds rate along with reserve balances during this period using a dual scale. Observe that there is a close negative correlation between the interest rate and the quantity of reserve balances during this period. Clearly there was downward pressure on the interest rate, rather than upward pressure. Figure 11 looks like the effects of a supply curve moving out along a downward sloping demand curve for reserves, rather than a demand curve moving out along a supply curve, even if that supply curve was itself moving out with demand as in the case of a classic accommodation move.

The decisions of the FOMC during this period are useful to examine in this context. The FOMC voted to cut the federal funds rate three times during this period. On Oct 8 it voted to cut it to 1.5 percent from 2.0 percent. But for the two weeks ending October 8 the effective federal 
funds rate was already well below 2.0 percent, averaging 1.45 percent. On October 29 the FOMC voted to cut the federal funds rate to 1 percent from 1.5 percent, but for the two weeks ending October 29 the effective federal funds rate was already below 1.5 percent, averaging .76 percent. On December 16 the FOMC voted to take the funds rate to a range of from 0 to .25 percent from 1 percent, but the rate was already in that range, averaging .14 percent for two weeks ending December 17. Thus, it appears that decisions that resulted in an increase in reserve balances were what drove down the funds rate rather than the FOMCs votes about the rate. Only after the fact did the FOMC vote to take the rates down. . A subject for future research is why, as shown in Figure 11, reserve balances temporarily decreased and the funds rate temporarily rose at the time of the FOMC meetings.

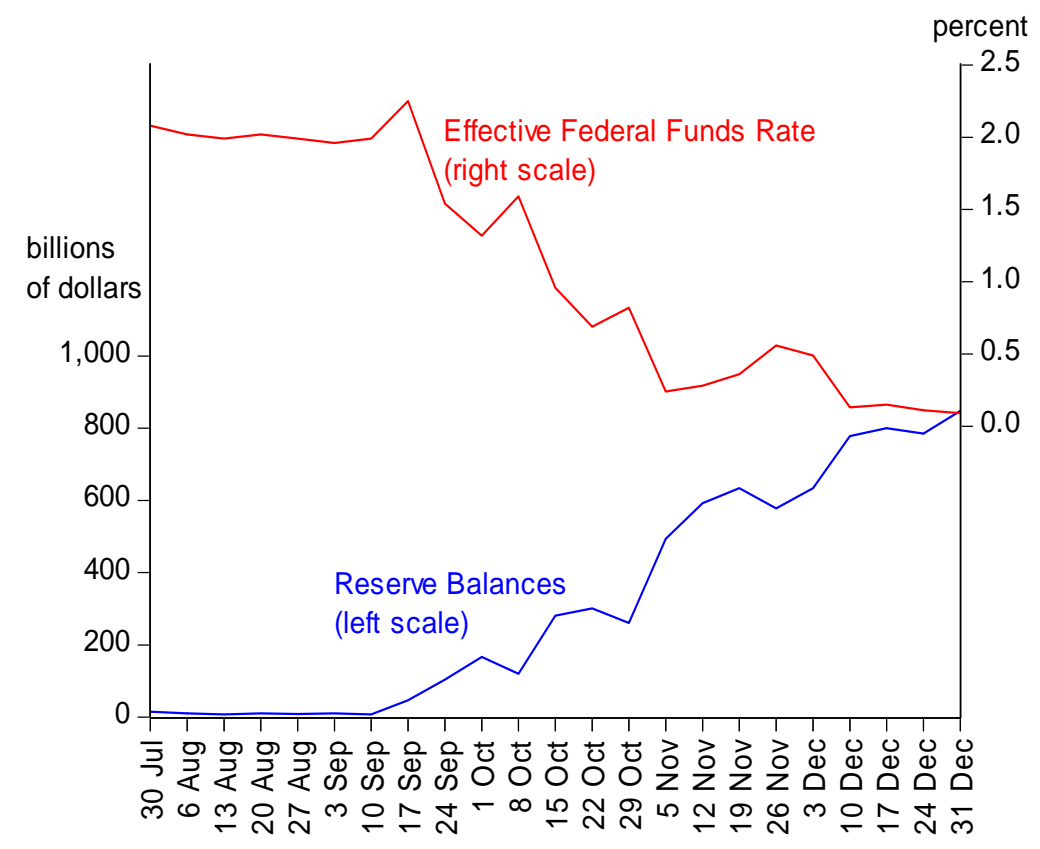

Figure 11. The Federal Funds Rate and Reserve Balances 
A related explanation for the increase in reserve balances is that the Fed started paying interest on reserves, which would be expected to increase the quantity of reserve balances demanded. However, the timing is way off for this explanation to make sense. The Fed announced it would pay interest on reserves on October 6, but reserve balances had already reached about $\$ 200$ billion by then. The Fed altered the formula effectively to pay more on November 5, but reserve balances were already at $\$ 500$ billion by then. It does not appear that paying interest on reserves was much of a factor in the rapid growth of reserve balances.

Yet another explanation is that there was an increase in the demand for currency, demand deposits, and other checkable deposits by the public. Such an increase could have generated an increased demand for central bank money. In fact both currency and demand deposits rose quite rapidly during this period as shown in Figure 12, reflecting lower interest rates and flight from money market mutual funds.

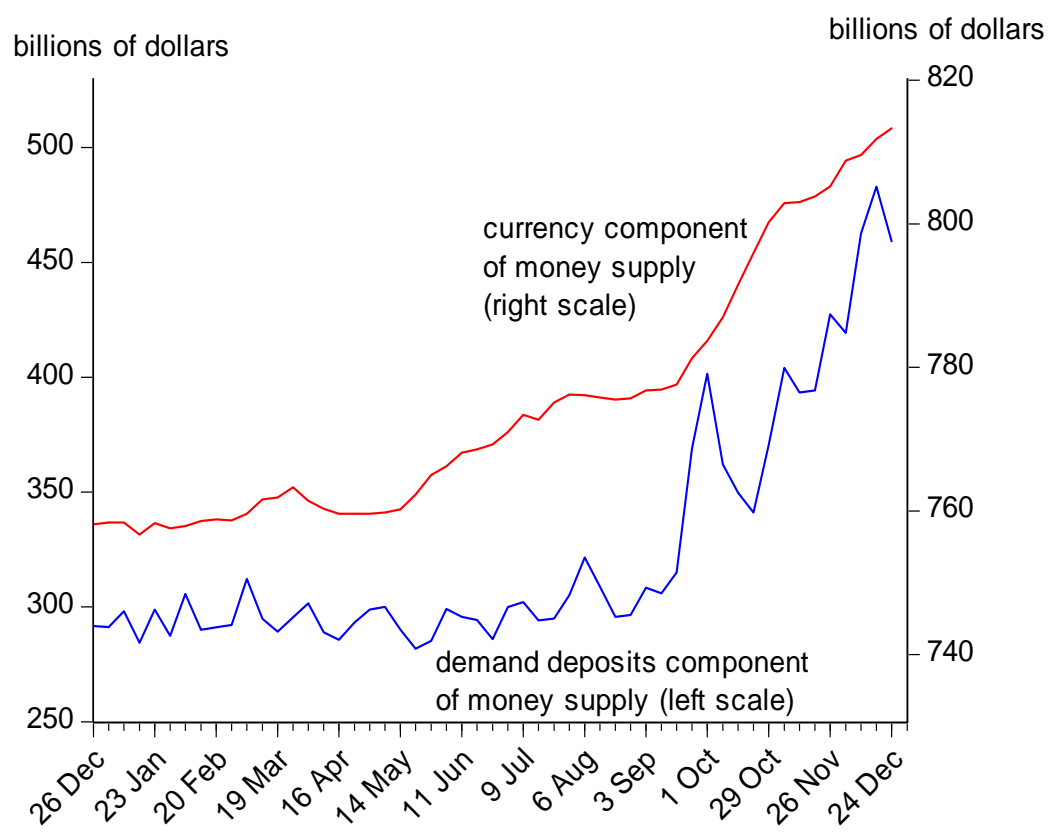

Figure 12. Growth of Currency and Demand Deposits in 2008 
But both currency and demand deposits rose much less rapidly than reserve balances as shown in Figure 13 which compares M1 with reserve balances plus currency. Hence the money multiplier fell sharply.

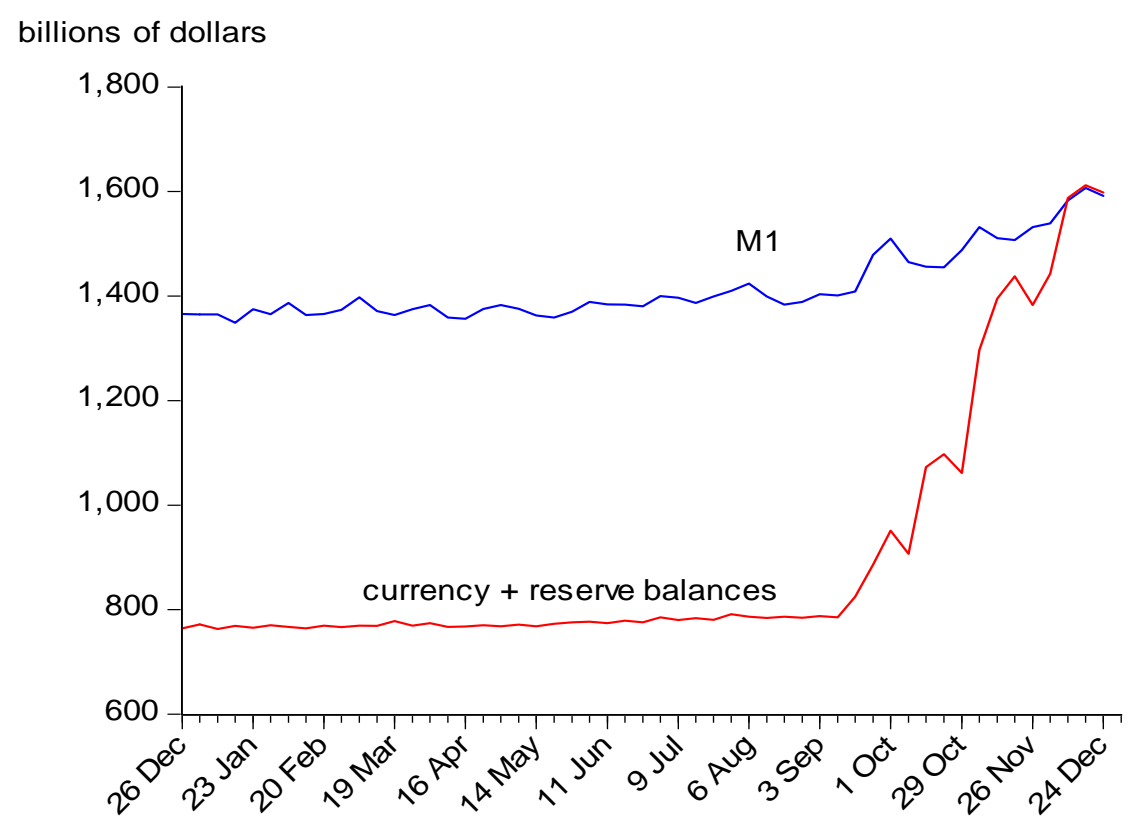

Figure 13. M1 and Currency plus Reserve Balances

\section{Concluding Remarks}

The purpose of this paper has been to explain how the explosion of reserve balances in the last few months of 2008 came about. Although some have pointed to an increase in the demand for money or reserves due to flight to quality during the financial crisis, this examination of the dynamics of the Fed's balance sheet and other factors shows that it was due to the increase in loans and securities purchased by the Fed in order to assist specific firms and sectors.

There are three ways the Fed can finance such securities purchases and loans: 
1. The Fed can borrow the funds.

2. The Treasury can borrow the funds and deposit them at the Fed.

3. The Fed can print money, that is create bank deposits at Federal Reserve Banks.

So far the Fed has mainly used the third method. It has used the second to some extent and it has avoided the first completely. While the first and the second methods have the advantage of not increasing the supply of money more than is desired for price stability purposes, they raise legal and political issues about using Treasury or Fed borrowing to allow the Fed to invest in certain sectors or firms without specific authorization. If we are to have an extensive industrial policy, it should be approved by the Congress with the purposes stated and debated transparently.

But rather than go further in this direction it would be more appropriate for the Fed to begin to move back to monetary policy rather than what I have called here mondustrial policy. The FOMC could start by reducing the growth of reserve balances and or even bringing them down. It could ask the Federal Reserve staff to study the impact of various growth rates for the quantity of reserve balances or the money supply, and discuss and vote on these quantities, at least until such time as the interest rate goes above zero. The Fed could refrain from using the Treasury to borrow funds for these specific interventions by the Fed. It could state that it does not plan to borrow itself in order to finance loans to certain markets and sectors.

It may be difficult for the Fed to move in this direction or to exit from its current policy. It is already going down a path to purchase $\$ 700$ billion more in securities backed by mortgages, credit card debt, student loans, and auto loans. It has stated that these actions are necessary because of the financial crisis. But are there no limits to increasing the size of such purchases in the future? And once the Fed owns these securities they will be politically difficult to sell. 
But if the Fed does not move in this direction, a number of questions need to be asked. What justification is there for an independent government agency to engage in such industrial policy? What is the role of District Bank presidents versus Board members in making such decisions? How can one continue to apply the section 13(3) "unusual and exigent” clause of the Federal Reserve Act when firms and people assisted can get credit but at a rate that seems too high? Will such interventions only take place in recessions, or will Fed officials use them in the future to try to make economic expansions stronger or to assist certain sectors and industries for other reasons? 


\section{References}

Christiano, Lawrence and Massimo Rostagno (2001), “Money Growth Monitoring and the Taylor Rule,” National Bureau of Economic Research, Working Paper 8539.

McCallum, Bennett T. (1988) “Robustness Properties of a Monetary Policy Rule,” CarnegieRochester Conference on Public Policy, Vol. 29, 173-204

Taylor, John B. (2000) “Expectations, Open Market Operations, and Changes in the Federal

Funds Rate,” Review, Federal Reserve Bank of St. Louis, Vol. 83, No. 4, July-August, pp 33-48

Taylor, John B. (2001), “Low Inflation, Deflation, and Policies for Future Price Stability,” Monetary and Economic Studies, Vol. 19, No. S-1, February. 